\title{
EFEKTIVITAS PENYULUHAN KESEHATAN GIGI DAN MULUT GURU PEMBINA KEPADA SISWA TUNA NETRA UPT RSCN MALANG DALAM MENINGKATKAN PENGETAHUAN DAN KETERAMPILAN SEBAGAI USAHA PREVENTIF ORAL HYGIENE
}

\author{
Yully Endang HM, Ria Puspitasari \\ *Departemen IKGMP Fakultas Kedokteran Gigi Universitas Brawijaya \\ **Poliklinik Universitas Brawijaya \\ Korespondensi: Yully Endang HM, E-mail: yullyehm@gmail.com
}

\begin{abstract}
ABSTRAK
Kesehatan gigi dan mulut dewasa ini sudah mulai diperhatikan secara seksama oleh masyarakat. Namun banyak faktor yang enghambat informasi tersebut sehingga dapat menimbulkan masalah kesehatan gigi dan mulut seperti halnya pada penderita tuna netra. Pentinglah bagi para guru pembina khusus untuk memberikan pengetahuan dan keterampilan mengenai pentingnya dan bagaimana cara menjaga kebersihan gigi dan mulut bagi para penderita tuna netra. Tujuan: Untuk meningkatkan pengetahuan dan keterampilan kepada pembina siswa tuna netra agar dapat menjadi penyuluh kesehatan gigi dan mulut bagi tuna netra. Metode: Peneliti mengadakan pre-test dan posttest pada siswa tuna netra sebelum dan sesudah diadakan penyuluhan untuk mengetahui apakah penyuluhan dapat meningkatkan pengetahuan dan keterampilan siswa terhadap kesehatan gigi dan mulut. Peneliti melakukan penyuluhan sebanyak dua kali yaitu pada guru pembina dan pada siswa tuna netra dengan materi plak, kalkulus, karies, dan cara menyikat gigi dengan benar. Hasil: Uji statistik Wilcoxon dengan SPSS menunjukkan angka signifikansi kurang dari alpha 0,05 sehingga Ho ditolak. Hal ini menunjukkan bahwa terdapat perbedaan yang signifikan antara nilai post-test pada sebagian besar responden lebih tinggi dibandingkan dengan nilai pre-test. Kesimpulan: penyuluhan memberikan pengaruh terhadap peningkatan pengetahuan dan keterampilan siswa tuna netra terhadap kesehatan gigi dan mulut.
\end{abstract}

Kata Kunci: penyuluhan, tuna netra oral hygiene 


\title{
THE EFFECTIVENESS OF DENTAL HEALTH AND MOUTH TEACHERS COUNSELING FOR TUNA NETRA STUDENT OF UPT RSCN MALANG STUDENTS IN IMPROVING KNOWLEDGE AND SKILLS AS A PREVENTIVE OF ORAL HYGIENE
}

\begin{abstract}
Today's dental and oral health has begun to be considered carefully by the community. However, many factors hamper this information so that it can cause dental and oral health problems as well as blind people. It is important for special counseling teachers to provide knowledge and skills about the importance and how to maintain dental and oral hygiene for blind people. Objective: To increase knowledge and skills to coach students with visual impairments so they can become dental and oral health educators for the visually impaired. Method: The researcher conducted a pre-test and posttest on blind students before and after counseling to find out whether counseling could improve students' knowledge and skills on dental and oral health. The researcher carried out counseling twice, namely to the counseling teacher and to blind students with plaque material, calculus, caries, and how to brush their teeth properly. Results: The Wilcoxon statistical test with SPSS shows a significance level of less than alpha 0.05 so that $\mathrm{Ho}$ is rejected. This shows that there are significant differences between the post-test scores on the majority of respondents higher than the value of the pre-test. Conclusion: counseling has an influence on increasing the knowledge and skills of blind students on dental and oral health.
\end{abstract}

Keywords: counseling, blind, oral hygiene

PENDAHULUAN

Penyuluhan kesehatan merupakan kegiatan pendidikan yang dilakukan dengan cara menyebarkan pesan, menanamkan keyakinan sehingga masyarakat tidak saja sadar, tahu, dan mengerti, tetapi juga mau dan bisa melakukan suatu anjuran yang ada hubungan dengan kesehatan. ${ }^{1}$ Penyuluhan kesehatan adalah penambahan pengetahuan dan kemampuanseseorang melalui teknik praktik belajar atau instruksi dengan tujuan mengubah ataumempengaruhi perilaku manusia baik secara individu, kelompok maupun masyarakatuntuk meningkatkan kesadaran akan nilai kesehatan sehingga dengan sadar maumengubah perilakunya menjadi perilaku sehat. ${ }^{2}$ 
Kebersihan gigi dan mulut tergantung

pada masing-masing kebiasaan dan

pengetahuan masing-masing individu, dimulai dari kebiasaan waktu dan cara menggosok gigi serta makanan-makanan yang dapat merusak gigi. Upaya peningkatan kebersihan mulut ini sekaligus merupakan upaya pencegahan penyakit gigi dan mulut. Pengetahuan dan perilaku masyarakat tentang upaya meningkatkan dan menjaga kebersihan mulut salah satunya dapat diperoleh dari media elektronik (televisi) yang dapat dilihat setiap hari, dari media cetak yang dapat dibaca, maupun peragaan penyuluhan oleh dokter gigi atau kader-kader kesehatan. Mata memiliki fungsi sebagai tranmisi visual yang mampu memberikan kontribusi sekitar 80-85 \% dalam perekaman interaksi manusia selama terjaga. ${ }^{3}$

Tunanetra adalah individu yang indra penglihatannya (keduanya) tidak berfungsi sebagai saluran penerima informasi dalam kegiatan sehari-hari seperti halnya orang awas. ${ }^{4}$ Orang tunanetra itu belum tentu buta, sedangkan orang buta itu pasti tunanetra. Di dalam bidang medik ketunanetraan mengandung arti atau implikasi suatu penyakit atau kondisi di mana visual mengalami kerusakan struktural, fungsional maupun keduanya.

Kesehatan gigi dan mulut adalah merupakan bagian integral dari kesehatan secara umum. ${ }^{5}$ Status kesehatan gigi tunanetra sampai saat ini belum banyak dilaporkan. Pihak yang berkompeten (Depkes) sampai saat ini belum memberikan laporan tentang status kesehatan gigi para penyandang tunanetra. ${ }^{6}$ Pemeliharaan kesehatan gigi dan mulut masih merupakan tantangan yang utama dalam perawatan terhadap tunanetra. Sedikit sekali informasi mengenai pencegahan kesehatan gigi dan mulut pada penderita tunanetra dalam daftar kepustakaan gigi.

Individu tunanetra tidak mempunyai kemampuan untuk melihat dan mengontrol kebersihan mulutnya. ${ }^{6}$ Cara menyikat gigi dan cara menggunakan dental floss untuk orang tunanetra tidak jauh berbeda dengan orang yang berpenglihatan normal kecuali pada orang tunanetra digunakan jari untuk menentukan letaknya yang benar di mulutnya.

Meninjau dari kasus-kasus khusus seperti pada kebersihan gigi dan mulut pada penderita tunanetra, diperlukan adanya tindakan yang intensif penyampaian informasi atau pengetahuan dan keteraampilan, seperti penyuluhan, yang tidak dapat dilakukan oleh sembarang media maupun sembarang orang. Media yang dipergunakan haruslah yang dapat diterima dengan baik oleh para penderita. ${ }^{2}$ Orang yang menyampaikan haruslah orang yang mengenal serta dapat memperlakukan tunanetra secara tepat, hal ini disebabkan karena tidak semua orang dapat berkomunikasi dengan baik dengan para tunanetra. Dilihat dari keadaan tersebut, maka pentinglah bagi para guru pembina khusus untuk memberikan pengetahuan dan keterampilan mengenai pentingnya dan bagaimana cara menjaga kebersihan gigi dan mulut bagi para penderita tuna netra. Berdasarkan uraian diatas, maka peneliti akan melakukan penyuluhan kepada guru pembina siswa tunanetra dalam meningkatkan pengetahuan dan keterampilan kesehatan gigi dan mulut siswa tuna netra di UPT RSCN Malang. 
METODE

Jenis penelitian yang digunakan dalam penelitian ini adalah eksperimen semu dengan rancangan group pre-test post-test design, dimana upaya peningkatan kesehatan gigi dan mulut ini diukur sebelum dan setelah diberikan perlakuan berupa penyuluhan kesehatan dari guru pembina siswa tuna netra. Penarikan kesimpulan di ambil dengan cara uji Paired-T tes dengan tingkat kemaknaan $a=5 \%$. Populasi dalam penelitian adalah semua siswa tuna netra di Unit Pengelola Tekhnis Rehabilitasi Sosial Cacat Netra (UPT RSCN) Malang sebagai sasaran penyuluhan. Jumlah siswa tuna netra di UPT RSCN Malang adalah $\leq 111$ siswa. Teknik Sampling yang digunakan dalam penelitian ini adalah cluster sampling, yaitu pengambilan sampel secara keseluruhan berdasarkan kelompok tiap kelas.

Peneliti akan terlebih dahulu memberikan penyuluhan kepada para guru pembina, sebelum guru pembina meneruskan materi penyuluhan pada siswa tuna netra. Penyuluhan ini menggunakan bantuan media flip-chart (lembar balik), book-leat, poster, alat peraga (panthom gigi, sikat gigi), serta alat tulis. ${ }^{6}$ Pemberian materi pada siswa tuna netra dengan sedikit modifikasi, yaitu dengan bantuan alat peraga (panthom gigi, sikat gigi), lagu-lagu mengenai kesehatan gigi dan mulut yang sudah sering terdengar, dan sedikit bacaan mengenai kesehatan gigi dan mulut berupa huruf braille yang diperikan oleh para pembina.

\section{HASIL}

Data yang didapatkan dari penelitian ini berupa karakteristik umum siswa tuna netra berupa jenis kelamin dan umur yang ditampilkan dalam bentuk tabel distribusi frekuensi, serta data hasil pre-test sebelum dilakukan penyuluhan dan data hasil post test setelah dilakukan penyuluhan. Untuk mengetahui apakah nilai pre-test terdapat peningkatan pada saat post-test maka dilakukan uji beda 2 sampel berpasangan.

Karakteristik umum responden dibagi berdasarkan jenis kelamin, umur, dan kategori kelas. Berikut ini hasil penelitian yang didapatkan.

Tabel 1. Distribusi Frekuensi Responden berdasarkan Jenis Kelamin.

\begin{tabular}{|c|c|c|c|}
\hline No. & $\begin{array}{c}\text { Jenis } \\
\text { Kelamin }\end{array}$ & Frekuensi & $\begin{array}{c}\text { Persen } \\
(\mathbf{\%})\end{array}$ \\
\hline 1 & Perempuan & 23 & 37,7 \\
\hline 2 & Laki-laki & 38 & 62,3 \\
\hline \multicolumn{2}{|c|}{ Total } & 58 & 100,0 \\
\hline
\end{tabular}

Berdasarkan karakteristik jenis

kelamin, didapatkan bahwa responden sebagian besar berjenis kelamin laki-laki yaitu berjumlah 38 orang $(62,3 \%)$.

Tabel 2. Distribusi Frekuensi Responden

Berdasarkan Umur

\begin{tabular}{|c|c|c|c|}
\hline No. & Umur & Frekuensi & Persen \\
\hline 1 & 15-20 tahun & 11 & 18.03279 \\
\hline 2 & 21-25 tahun & 21 & 34.42623 \\
\hline 3 & 26-30 tahun & 10 & 16.39344 \\
\hline 4 & 31-35 tahun & 6 & 9.836066 \\
\hline 5 & 36-40 tahun & 9 & 14.7541 \\
\hline 6 & 41-45 tahun & 3 & 4.918033 \\
\hline 7 & 46-51 tahun & 1 & 1.639344 \\
\hline \multicolumn{2}{|r|}{ Total } & 61 & 100 \\
\hline
\end{tabular}

paling banyak adalah berumur antara 21 hingga 25 tahun yaitu sebanyak 21 responden $(34,43 \%)$. 
Tabel 3. Distribusi Frekuensi Responden

Berdasarkan Kelompok Kelas

\begin{tabular}{|c|c|c|c|}
\hline No & Kelas & Frekuensi & Persen \\
\hline 1 & $\begin{array}{c}\text { Kelas } \\
\text { Persiapan A }\end{array}$ & 26 & 42.62295 \\
\hline 2 & $\begin{array}{c}\text { Kelas } \\
\text { Persiapan B }\end{array}$ & 16 & 26.22951 \\
\hline 3 & Kelas Dasar & 15 & 24.59016 \\
\hline 4 & Kelas Praktis & 4 & 6.557377 \\
\hline \multicolumn{2}{|r|}{ Total } & 61 & 100 \\
\hline
\end{tabular}

responden berdasarkan kelas. Berdasarkan tabel tersebut didapatkan bahwa responden terbanyak berasal dari kelas persiapan A yaitu sebanyak 26 responden (42,63\%).

Pengetahuan dan keterampilan mengenai kesehatan gigi dan mulut diukur dengan kuesioner yang berisi 20 pertanyaan. Pertanyaan-pertanyaan tersebut diberikan kepada 61 responden sebelum dan sesudah diberikan penyuluhan. Distribusi perubahan jawaban responden dari pre-test ke post-test ditunjukkan pada Tabel 4 berikut:

Tabel 4. Distribusi Perubahan Nilai pretest ke post-test

\begin{tabular}{|c|c|c|c|}
\hline No & $\begin{array}{c}\text { Perubahan } \\
\text { Nilai }\end{array}$ & Frekuensi & $\begin{array}{c}\text { Persen } \\
(\%)\end{array}$ \\
\hline 1 & post < pre & 1 & 1.639344 \\
\hline 2 & post $>$ pre & 53 & 86.88525 \\
\hline 3 & post $=$ pre & 7 & 11.47541 \\
\hline \multicolumn{2}{|r|}{ Total } & 61 & \\
\hline
\end{tabular}

banyak responden mengalami perubahan nilai meningkat dari pre-test ke post-test yaitu sebanyak 53 responden $(86,88 \%)$

Berdasarkan Tabel 4, dapat diketahui bahwa sebagian besar responden memiliki peningkatan nilai dari pre-test ke post-test. Untuk mengetahui apakah perbedaan atau perubahan nilai tersebut signifikan maka harus diuji menggunakan uji beda sampel. Uji beda 2 sampel secara parametrik adalah menggunakan uji paired t-test. Uji parametrik mensyaratkan terpenuhinya asumsi kenormalan data. Dalam penelitian ini uji kenormalan menggunakan statistic uji Kolmogorov-Smirnov dengan kriteria keputusan jika signifikansi lebih besar dari alpha atau Ho diterima maka data mengikuti distribusi normal atau asumsi kenormalan terpenuhi. Hasil uji kenormalan untuk data nilai pre-test dan posttest adalah sebagai berikut:

Tabel 5. Hasil Uji Kenormalan Data pretest dan post-test

\begin{tabular}{|l|c|c|}
\hline \multicolumn{1}{|c|}{ Hasil Uji } & Pre & post \\
\hline $\begin{array}{l}\text { Kolmogorov- } \\
\text { Smirnov Z }\end{array}$ & 1.429713 & 3.012593 \\
\hline $\begin{array}{l}\text { Signifikansi atau } \\
p \text {-value }\end{array}$ & 0.03354 & $2.62 \mathrm{E}-08$ \\
\hline
\end{tabular}

Uji kenormalan menggunakan Kolmogorov-Smirnov menunjukkan bahwa nilai signifikansi atau $p$-value kurang dari alpha 0,05 sehingga $\mathrm{H} 0$ ditolak yang menunjukkan bahwa asumsi kenormalan tidak terpenuhi. Jika asumsi kenormalan tidak terpenuhi maka uji parametrik tidak bisa dilakukan dan harus menggunakan uji non parametrik. Uji nonparametrik untuk data 2 sampel berpasangan adalah uji Wilcoxon.

Tabel 6 menunjukkan hasil uji wilcoxon hasil uji wilcoxon menggunakan software SPSS. Berdasarkan tabel tersebut didapatkan signifikansi atau $p$-value kurang dari alpha 0,05 $(0,000)$, sehingga Ho ditolak. Hal ini mengindikasikan bahwa terdapat perbedaan yang signifikan antara nilai pre-test dan posttest di mana sebagian besar responden memiliki nilai post-test yang lebih tinggi dibanding pre-test. Nilai post-test yang lebih tinggi ini menunjukkan bahwa penyuluhan 
mengenai kesehatan gigi dan mulut memiliki pengaruh terhadap peningkatan pengetahuan dan keterampilan kesehatan gigi dan mulut.

\section{PEMBAHASAN}

Dalam institusi ini, guru mempunyai peran yang sangat penting terutama dalam hal mengarahkan dan membina pengetahuan anak tunanetra tentang kenyataan yang ada di sekitarnya, juga menumbuhkan kepercayaan diri serta menanamkan perasaan bahwa dirinya dapat diakui dan diterima oleh lingkungannya. ${ }^{7}$ Diharapkan setelah lulus dari UPT RSCN tersebut, siswa tunanetra dapat melakukan rutinitas sehari-hari secara mandiri tanpa meminta bantuan orang lain serta mempunyai keahlian demi meningkatkan taraf hidupnya.

Dalam penelitian ini, penyuluhan kepada guru pembina merupakan salah satu upaya dalam meningkatkan pengetahuan danketerampilanmengenai kesehatan gigi dan mulut siswa-siswi tunenetra di UPT RSCN Malang. Penyuluhan kepada guru pembina ini bertujuan agar para guru pembina dapat membantu peneliti untuk menyampaikan informasi dan materi penyuluhan kepada siswasiswi tunanetra. Selain itu, untuk kedepannya para guru pembina diharapkan dapat terus menyampaikan materi mengenai kesehatan gigi dan mulut tersebut secara kontinyu di setiap harinya dan juga memberikan materi ini kepada para siswa baru yang masuk di UPT RSCN Malang.

Penyuluhan guru pembina siswa tunanetra ini dihadiri oleh 17 guru pembina dengan materi penyuluhan mengenai plak, kalkulus, karies, dan cara menyikat gigi yang benar. Pada setiap bab berisi mengenai definisi, patogenesa, cara mencegah, penatalaksanaan, gambar-gambar yang mendukung materi, dilakukan dengan metode ceramah serta dilanjutkan dengan demonstrasi cara menyikat gigi dengan benar. Penyuluhan yang dilakukan sekitar kurang lebih satu jam ini mendapatkan respon yang sangat baik dari para guru. Hal ini dibuktikan dengan sesi tanya jawab yang dilakukan selama setengah jam dipenuhi dengan 12 pertanyaan dari para guru pembina. Timbal balik yang sangat baik dari para guru pembina, para guru sangat mendukung diadakannya penyuluhan ini karena belum ada peyuluhan mengenai kesehatan gigi dan mulut bagi para guru pembina maupun siswa tunanetra.

Dalam penelitian ini populasi yang digunakan adalah sebanyak 111 siswa tunanetra di UPT RSCN Malang. Berdasarkan kriteria inklusi dan eksklusi, maka didapatkan bahwa sebanyak 61 siswa tunanetra yang memenuhi kriteria inklusi sehingga responden dalam penelitian ini adalah sebanyak 61 siswa tunanetra.

Penyuluhan yang dilakukan oleh penyuluh dan dibantu oleh guru pembina dalam penelitian ini berisikan materi yang sama dengan yang diberikan pada saat penyuluhan bagi para guru pembina, yaitu mengenai plak, kalkulus, karies, serta cara menyikat gigi dengan benar. Bedanya, alat bantu seperti gambar tidak dapat digunakan pada penyuluhan pada siswa tunanetra. Materi berisikan definisi, patogenesa, pencegahan, serta penatalaksanaan yang diberikan dengan metode ceramah dan tanya-jawab, selanjutnya diberikan simulasi cara menyikat gigi dengan benar. Simulasi diberikan dengan cara 
membagi siswa-siswi dalam kelompokkelompok kecil berisikan 4-5 siswa per kelompok dan dibimbing oleh satu mahasiswa dari PSPDG. Dimulai dengan perabaan sikat gigi yang digunakan dan phantom yang diumpamakan gigi masing-masing siswa. Perabaan panthom setiap sisi gigi kemudian penjelasan dan praktik arah penyikatan dan cara menyikat yang benar di tiap sisi gigi.

Antusiasme siswa-siswi tunanetra sangat baik, dilihat dari jalannya penyuluhan yang berlangsung sekitar kurang lebih satu jam yang mendapat perhatian penuh dari para siswa tunanetra, kemudian dilanjutkan dengan memberi kesempatan para siswa untuk bertanya selama 30 menit yang dimanfaatkan para siswa bertanya seputar kesehatan gigi dan mulut pribadi maupun keluarganya. Demikian pula secara nyata terlihat pada peningkatan nilai dari pretest ke posttest sesuai yang dibahas pada Bab V. Siswa-siswi penyuluhan pun kooperatif dilihat dari bagaimana mereka mudah menerima informasi dan tanggap terhadap simulasi yang diberikan. Diharapkan materi penyuluhan yang telah diberikan akan tetap selalu diingat dan dipraktikkan secara pribadi serta dapat disosialisasikan kepada teman, keluarga, dan orang lain saat kembali ke rumah masing-masing.

Dari penelitian yang telah dilakukan mengenai upaya peningkatan pengetahuan kesehatan gigi dan mulut pada siswa tunanetra, ternyata terlihat pengetahuan kesehatan gigi dan mulut sebelum dan sesudah penyuluhan dari hasil pre test dan post test secara kasar terlihat pada tabel 5.4 mengalami peningkatan yaitu sebanyak 53 responden (86,88\%). Dari masing-masing kelas dapat diketahui peningkatan rata-rata hasil pretest dan posstest, antara lain :

Tabel 7. Rata-rata nilai Pre-Test dan Post Test siswa

\begin{tabular}{|c|c|c|c|}
\hline Kelas & Rata- & Rata- & Persentase \\
& rata & rata & peningkatan \\
& Nilai & Nilai & \\
& Pre- \\
Test & $\begin{array}{r}\text { Post- } \\
\text { Test }\end{array}$ & \\
\hline Persiapan A & 80 & 96,7 & $16,7 \%$ \\
\hline Persiapan B & 79 & 97,8 & $18,8 \%$ \\
\hline Kelas dasar & 81 & 99 & $18 \%$ \\
\hline KelasPraktis & 77,5 & 90 & $12,5 \%$ \\
\hline
\end{tabular}

Dari hasil uji distribusi kenormalan data dengan menggunakan uji kolmogorov smirnov didapatkan nilai signifikansi asumsi kenormalan tidak terpenuhi sehingga menggunakan rancangan analisis uji Wilcoxon. Dari hasil uji Wilcoxon didapatkan signifikansi atau $p$-value yang kurang dari alpha 0,05 sehingga Ho ditolak. Hal ini mengindikasikan bahwa terdapat perbedaan yang signifikan antara nilai pre-test dan post-test di mana sebagian besar responden memiliki nilai post-test yang lebih tinggi dibanding pre-test. Didapatkan kesimpulan bahwa penyuluhan mengenai kesehatan gigi dan mulut yang dilakukan pada guru pembina dan siswa tuna netra memiliki pengaruh terhadap peningkatan pengetahuan kesehatan gigi dan mulut siswa tuna netra.

\section{KESIMPULAN}

1. Responden yang digunakan pada penelitian ini adalah sebagian besar berjenis kelamin laki-laki, berumur 21 hingga 25 tahun dan berasal dari kelas persiapan $\mathrm{A}$ 
2. Sebagian besar responden memiliki kenaikan nilai tingkat pengetahuan pada saat sebelum diberikan penyuluhan dan sesudah diberikan penyuluhan dan perbedaan nilai sebelum diberikan penyuluhan dan sesudah diberikan penyuluhan tersebut signifikan secara statistik

3. Penyuluhan berpengaruh terhadap peningkatan tingkat pengetahuan dan keterampilan siswa tuna netra terhadap kesehatan gigi dan mulut

\section{DAFTAR PUSTAKA}

1. Fitriani S. Promosi Kesehatan. Graha Ilmu. Yogyakarta. 2011.

2. Lusiani Y. Efektivitas Penyuluhan yang Dilakukan oleh Perawat Gigi dan Guru Orkes dalam Meningkatkan Perilaku
Pemeliharaan Kesehatan Gigi dan Mulut Pada Murid SD. Medan. 2010.

3. Sadiman, A. Pengaruh Televisi terhadap Perubahan Perilaku. Pusat Tekhnologi dan Komunikasi, Jakarta. 2001.

4. Soemantri T, Sutjihati. Psikologi Anak Luar Biasa. PT. Refika Aditama, Bandung. 2006.

5. Depkes. Profil Kesehatan Indonesia tahun 2011. Kementerian Kesehatan Republik Indonesia. Jakarta. 2012.

6. Heriyanto Y. Hubungan antara Pengetahuan, Persepsi dan Sikap terhadap Kesehatan Gigi dengan Status Kesehatan Gigi pada Siswa Tuna Netra di Panti Sosial Bina Netra (PSBN) WyataGuna Bandung. Sains Kesehatan. 2005; 18(2).

7. Efendi M. Pengantar Psikopedagogik Anak Berkelainan. Bumi Aksara, Jakarta. 2006. 